\title{
CHRONOLOGICAL TABLE
}

Tiberius' Age

B.C.

44 Assassination of Caesar (March 15 ).

43 Octavian consul (August). Triumvirate formed (November).

42 Ti. Nero praetor. Philippi (October). Birth of Tiberius (November 16).

4I I

40 Fall of Perusia (February). Pact of Brundisium (October). 2

39 Pact of Misenum (spring). 3

38 Birth of Drusus (January 14). Marriage of Octavian and Livia 4 (January 17 ).

37 Pact of Tarentum (spring).

Death of Ti. Nero. ?Betrothal of Tiberius and Vipsania.

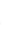

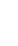

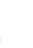

3 Actium (September).

30

29 Octavian's triumph (August $13-15$ ).

28

27

Octavian called Augustus (January). Tiberius assumes toga 15 uirilis (April 24).

26 Tiberius in Spain as military tribune.

25 Marriage of Marcellus and Julia. $\quad$ I7

$24 \quad 18$

23 Augustus resigns consulship, receives tribunician power. I9 Tiberius quaestor, Marcellus aedile. Death of Marcellus.

22 Tiberius prosecutes Fannius Caepio. 20

2 Marriage of Agrippa and Julia. 2 I 
B.C.

20 Tiberius in Armenia. Birth of C. Caesar. ?Marriage of 22 Tiberius and Vipsania.

19 Augustus' imperium made valid inside Rome. 23

I8 Agrippa receives tribunician power. 24

I7 Birth of L. Caesar. Adoption of Gaius and Lucius. 25

I6 Tiberius praetor. $\quad 26$

I5 Tiberius and Drusus in Rhaetia and Vindelicia. Birth of 27 Germanicus (May 24).

I4 ?Birth of Drusus (October 7). 28

I3 Tiberius consul. Agrippa's tribunician power renewed. 29

12 Death of Agrippa (February). Birth of Agrippa Postumus. 30 Betrothal of Tiberius and Julia. Tiberius to Illyricum.

I I Tiberius in Illyricum. Tiberius and Drusus receive pro- $3^{\mathrm{I}}$ consular imperium. Marriage of Tiberius and Julia.

Io Tiberius in Illyricum. Son born to Tiberius and Julia. 32

9 Drusus consul. Tiberius in Illyricum. Death of Drusus. 33

8 Tiberius in Germany. $\quad 34$

7 Tiberius consul I I. Tiberius' triumph (January). Tiberius in 35 Germany.

6 Tiberius receives tribunician power, retires to Rhodes. $\quad 36$

$5 \quad$ Gaius and Lucius principes iuuentutis.

$4 \quad 38$

$3 \quad 39$

2 Divorce of Tiberius and Julia. Exile of Julia. 40

I Gaius' mission to the East. $4 \mathrm{I}$

A.D.

I Gaius consul. $\quad 42$

2 Tiberius returns to Rome. Death of Lucius (August 20). 43

344

4 Death of Gaius (February 21). Tiberius receives tribunician 45 power. Adoption of Germanicus by Tiberius. Adoption of Tiberius and Agrippa Postumus by Augustus (June 26).

Tiberius to Germany.

5 Tiberius in Germany. 
A.D.

6 Pannonian revolt. $\quad 47$

7 Tiberius in Illyricum. $\quad 48$

8 Tiberius in Illyricum. $\quad 49$

9 Tiberius in Illyricum. Clades Variana. 50

Io Tiberius in Germany. $\quad 5 \mathrm{I}$

I I Tiberius in Germany.

12 Germanicus consul. Birth of Gaius (August 31). Tiberius' 53 triumph (October 23).

I3 Tiberius' imperium made equal with that of Augustus and his 54 tribunician power renewed.

I4 Death of Augustus (August 19). Execution of Agrippa 55 Postumus. Mutinies. Tiberius accepts principate (September 17). Germanicus in Germany. Death of Julia.

I5 Drusus consul. Tiberius pontifex maximus (March 10). ${ }_{56}^{6}$ Germanicus in Germany. Seianus sole praetorian prefect. Death of a son of Drusus.

I6 Germanicus in Germany. Trial of Libo (September). 57 Clemens.

I7 Germanicus' triumph (May 26). Drusus to Illyricum. $5^{8}$ Germanicus appointed to the East. Earthquake in Asia. Exile of Rhescuporis. Rebellion of Tacfarinas.

I8 Tiberius consul III, Germanicus consul II. Fall of 59 Maroboduus.

19 Death of Germanicus (October 10). Birth of Drusus' twins. 60

20 Trial of $\mathrm{Cn}$. Piso. Death of Vipsania. 6I

2I Tiberius consul Iv, Drusus consul II. Tiberius in Campania. 62 Trial of Clutorius Priscus. Revolt of Florus and Sacrovir.

22 Drusus receives tribunician power. Trial of C. Silanus. 63

23 Divorce of Seianus and Apicata. Death of Drusus (September 64 I4). Death of Drusus' son Germanicus.

24 Tiberius' province renewed. Trial of C. Silius. Death of 65 Tacfarinas.

25 Trial of Cremutius Cordus. Seianus refused Livia Julia. 66

26 Trial of Claudia Pulchra. Tiberius leaves Rome. 67

27 Tiberius retires to Capreae. 68 
A.D.

28 Trial of Titius Sabinus. Marriage of younger Agrippina and 69 Cn. Domitius Ahenobarbus. Revolt of Frisii.

29 Death of Livia. Exile of Agrippina and Nero. 70

30 Imprisonment of Asinius Gallus. Imprisonment of Drusus. 7I Betrothal of Seianus and Livia Julia.

3I Tiberius consul v, Seianus consul. Seianus executed (October 72 I8). Macro praetorian prefect. Death of Livia Julia.

32

33 Death of Asinius Gallus. Death of Drusus. Death of Agrippina (October 18). Financial crisis. Marriages: Gaius and Junia Claudilla; Drusilla and L. Cassius Longinus; Julia Livilla and M. Vinicius; Julia and C. Rubellius Blandus.

34 Tiberius' province renewed. Suicide of Mam. Scaurus.

35 Suicide of Fulcinius Trio. L. Vitellius in the East. $\quad 76$ 36

37 Suicide of L. Arruntius. Death of Tiberius (March 16). Funeral of Tiberius (April 3). 